\title{
CAPITAL STRUCTURE, PROFITABILITY AND FIRM VALUE: EVIDENCE FROM MINING COMPANIES
}

Diga Cendekia Budianto

KPMG Indonesia

Email: digabudianto@yahoo.com
Yosman Bustaman

Swiss German University, Tangerang, Indonesia

Email: jbustaman@gmail.com

This research investigates the impact of firm capital structure on profitability and firm value of the twenty eight mining companies listed in Indonesia Stock Exchange from the year 2009 to 2013. The capital structure is measured by the proportion of debt over total asset, ROA and ROE are used to measure the firm profitability, meanwhile stock price is applied to measure firm value. This study uses panel data regression analysis. After controlling with external factor such as GDP rate and inflation rate, and internal factor such as revenue growth and firm size (total asset), we find leverage has negative impact on ROA however they are not significant, thus it could be said capital structure has no effect on financial performance. The indicators that significantly affect financial performance come from the control variable, which is revenue growth. Our research also finds that the capital structure has a significant effect towards firm value. The firm size and GDP rate is more impactful towards firm value. This contradicts with the MM's capital structure irrelevance proposition, but supports other theories such as pecking order theory and Trade-off theory

Capital Structure, Financial Performance, Firm Value,

Indonesia Mining Industry 


\section{INTRODUCTION}

\section{I.I Background}

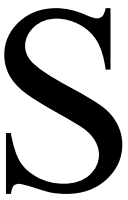
election of the capital structure and its impact on firm performance is a topic that has always been a debate among researchers. Examination conducted in some developing countries such as Jordan, Iran, Pakistan, SaudiArabia, and Sri Lanka. From this research, most of them found that capital structure and firm's performance have a negative relationship (Nirajini \& Priya, 2013; Pouraghajan, et.al 2012; Soumadi \& Hayajneh, 2012). Furthermore Dimitrov and Jain(2008) recorded negative correlation between leverage and risk adjusted return. However, there also someresearches that found a positive relationship between them. Mesulis (1983) shows that change in structure of capital is positively impact change in stock return, meanwhile (Bhandari, 1988) who test MM's preposition II prove that leverage has a significant positive effect on expected common stock return. Due to the difference results, this topic is always become interesting object for further research as we are going to do.

The company's decision to select a portion of the debt financing or equity capital will have an impact on the value of the company and also the cost of capital (Ross et.al, 2009). The critical point in determining a right capital structure is the management's responsibility to identify the proportion of debt and equity desirable by the company to enhance the company's value (Nirajini $\&$ Priya, 2013). Some research found that companies with high earnings are likely to have less debt compared to equity (Pastory, Marobhe, \& Kaaya, 2013). The financial managers are demanded to be able to decide the proportion of capital used to make it their perfect proportion of capital for their companies. Capital structure plays a role in determining the risk level of the company as the company decides its capital structure, the cost of capital arises (Nirajini \& Priya, 2013).

Companies who are issuing more shares, they have to consider their value. This is effecting the decision of shareholders. For example, , the stock dividend and earnings per share had a negative relationship with stock market price in Pakistan (Khan, 2012). This means when the stock market price increases, thus the dividend and earning per share decreases. When the earnings are lower and the price is high, thus investors are likely to sell its shares. The financial statement provides the operating performance accurately; however, stock price will reveal a broader set of information (Ak, Dechow, Sun, \& Wang, 2013). That information then becomes the consideration for the investors.

The decision of capital structure is a very critical issue in the organization. To decide the proportion of debt and equity, there must be costs and benefits. The consideration of the cost and benefit from both aspects needs to be well-thoughtout because it might effects the financial performance and/or the firm's value. Our research will focus on the Mining Sector Companies listed in the Indonesian Stock Exchange. This industry sector has been chosen because the product of this industry becomes the basic living needs for inhabitants. The study of capital structure in Mining Industry is attractive because the average proportion of capital structure is almost 50:50; total debt over total assets is $53 \%$ and total equity over total assets is $47 \%$. These capitals is mostly used to cover the fixed assets of these companies as Mining companies 
needs a lot and expensive machineries, or even renting the land to the Indonesian government. Thus, the main questions to be answered in this research are as follow: firstly how strong capital structure affects the financial performance, secondly how affective is the change in capital structure changes the firm value?

\section{I.II Literature Review}

The theory of capital structure was first built by Modigliani and Miller ( MM ) ( 1958 and 1963), the existence of an optimal capital structure to be in line with the balance between the risk of bankruptcy and tax shield. Optimum capital structure will yield greater returns to shareholders than if companies just rely entirely of equity financing. However, other empirical studies that emerged showed different results (Myers,1984). Besides the advantages of financing with debt ( leverage ), some companies are trying to escape from the existence of the debt ( Gardner and Trzcinka, 1992 at Margaritis , 2010) .

There are two main theories generally used to explain the corporate debt structure, i.e. the trade-off theory and the pecking order theory. Trade off theory arises due to the MM's irrelevance theory (Luigi $\&$ Sorin, 2009). This theory stated that firms seek debt levels that balance the tax advantages of additional debt against the cost of possible financial distress (Myers, Capital Structure, 2001). The issue is the existence of corporate income tax creates the costs and benefits of issuing debts or equities. Debt is cheaper than equity because it has no risk shared and it can be collateralized, while equity is claimed. The company can lower its capital cost through leverage. However, leverage would increase the financial risk, so the company must balance the costs and benefits (Jaisawal, Srivastava, \& Sushma, 2013). The financial risk means that the company is unable to pay the obligation which would cause bankruptcy. When this is the case, so the assets of the company are needed to be sold at a lower price than the value. The cost is not only the debt, there are also administrative and legal costs too (Nirajini \& Priya, 2013).

While the theory of packing order stating that the company has a hierarchy in its financing decisions, due to adverse selection the company preferred internal financing compare with outside financing. When outside financing are necessary needs, the company will seek debt funding first, raising equity capital is the last alternative (Myers, 1984; Myers and Majluf, 1984). Myers (2001) stated that the firm will borrow, rather than issuing equity, when internal cash flow is not enough to fund the expenditure; therefore, the debt reflects the firms' fund needed externally (Myers, 2001). Based on their research, the managers know better than the outside investors. When this is the case, the managers would likely to use this theory; use retained earnings to fund the company but if it is not enough, they would choose the lowest-risk debt and then issuing equities (Luigi \& Sorin, 2009). This is so because the richer the internal funds, the less the business risk they have. That is why highly profitable companies generally have less debt compared to those who need more funds (Chandra, 2011).

Several factors will affect the target debt ratio (optimum capital structure) on the static tradeoff theory as tax shield (Modiagliani and Miller, 1963); costs of financial distress; debt overhang problem (Myers 1977); cost of personal 
taxes (Miller 1977) non-debt tax shields (De Angelo et al, 1980 at Myers, 1984). Meanwhile Flannerary and Rangan (2006) on Simmerly and Li (2010) says that the optimum capital structure is influenced by the profitability, market-to-book ratio, depreciation, company size, tangibility, the cost of $R \& D$ and the number leverage of the industry and the factors macroeconomic like. Macroeconomic s a variable that is used by Choe et al (1993) Korajczyck and Levy (2003) on Simmerly and $\mathrm{Li}$ (2010).Choosing the right capital structure is an important decision for any type of company. This will impact not only to maximization its return to all stakeholders of the company, which in turn will increase the value of the company, but also will affect the company's ability to compete with its environment (Simmerly and Li 2000). Several studies of the financial and management strategies indicates that environmental factors will affect the capital structure decision. According to Bradley, Jarel and Kim (1984) there are three specific factors that affect the optimum capital structure; firstly the variability of the value of the company, secondly the potential impact of financial distress and lastlythe amount of non-debt tax shield. The variability of the company's revenue and the potential impact of financial distress of a bona fide negative relationship with the company's leverage, while the non-debt tax shield has a positive relationship with leverage. Research Thies and Klock (1992) in manufacturing companies showed that the variance in sales growth (reflecting increased environmental factors) resulted in a decrease in the value of the company's long-term debt. Furthermore, they also say that tax incentives increase the use of loans, bankruptcy and agency costs will reduce the desire for the use of the loan, while the asymmetric information will limit the use of debt.
Another strand of literature analyze relationship between ownership structure and company performance. Classical theory of agency concept proposed by Berle and Means (1932), their observations indicate that the ownership and control become separated in large companies because of the dilution of ownership. This then raises the opportunity for the professionals who lead the company to act as they interest (Walsh and Seward, 1990 at Simerly and Li (2000). According to Jensen (1976) the key issues of agency theory is how to resolve the conflict between business owners and managers to control of the resources of the company, using a contract that describes the rights and incentives for managers. Manager will assign a low level of leverage to be able to reduce the risk of bankruptcy and keep the human capital resources of the company (Jensen and Meckling, 1976, Fama, 1980 and Grossman and Hart, 1982). Meanwhile, according to Jensen (1986), the company will establish a high level of leverage as shareholders of the company does not want to do an over investment. To avoid the incentives for managers to act on his own and to increase the welfare of the owners Jensen proposed stock ownership to manager. Meanwhile Shleifer and Vishny (1988)argue that outside large capital owners of company can reduce agency conflicts due to strong incentives to monitor and to discipline management.

\section{IIDATA AND METHODOLOGY}

\section{II.I Data}

The unit analysis of this research is the company's in mining industry listed in Indonesia Stock Exchange. This research will be analyzing data which is the annual 
report published in Indonesian Stock Exchange website, Indonesia Statistic Center (BPS), and also Bank Indonesia. The time range of the data collected will be 5 years which is from 2009 until 2013. Criterion for the data are as follows; the companies should become publicly traded companies for at least 5 years and the annual report from 2009 to 2013 are provided. There are 28 among 38 companies have been fulfilling the criteria and therefore are chosen. We use data panel regression analysis to run our model using EViews version 7.

\section{II.II Empirical Models}

The models are used in our analysis as follows:

$$
\begin{aligned}
& \text { Profitability }_{i t}=\alpha+\beta \text { CapStr }_{i t}+\sum_{1}^{2} \gamma F S_{i t}+\sum_{1}^{2} \theta M E_{i t}+\epsilon_{i t} \ldots(2.1) \\
& \text { FirmValue }_{i t}=\alpha+\beta \text { CapStr }_{i t}+\sum_{1}^{2} \gamma F S_{i t}+\sum_{1}^{2} \theta M E_{i t}+\epsilon_{i t} \ldots(2.2)
\end{aligned}
$$

Where it subscribed indicates $i$ as the company observed at the time period of t. While $\varepsilon_{-}$it is the random error that is constant through the lengths of the time range. Firm performance measures by accounting performance using Return on Asset (ROA) and Return on Equity (ROE), we also use non accounting measurement of company's performance ie: stock price. ROE shows how well the company utilizes its capital from shareholders to generate profits. The higher the ROE means the better the performance (D'Amato, 2010). From the formula below, the net income is the profit after tax less preference dividends, while the denominator includes paid-up capital, reserves, and surplus (Chandra, 2011).

$$
R O E=\frac{\text { Net Income }}{\text { Average Shareholder's Equity }} \times 100 \ldots
$$

Pastoryet al (2013)used ROE to measure the financial performance. Their research indicate a negative relationship between the capital structure and performance of the banks. ROA shows how well a company utilizes its assets to generate income. It is best used when there is risk free rate of return because generating higher return seems good but if the other companies in the same industry generate higher return then it seems unimpressive. Essentially, the ROA generated by company supposed to be greater than the risk free rate of return to convince the shareholders to invest without doubt. If not, they would like to purchase bonds with a guaranteed yield (D'Amato, 2010). We use the formula (2.4), the numerator measures the return to shareholders whereas the denominator represents the contribution of all investors (Chandra, 2011).

$$
R O A=\frac{\text { Net Income }}{\text { Average Total Assets }} \times 100 \ldots
$$

Pratheepkanth (2011), Soumadi and Hayajneh (2012) used this ratio as a parameter to measure how well the firm performance is. Pratheepkanth's provide evidence that there is a weak positive relationship between ROA with capital structure. However, Soumadi and Hayajneh find that financial leverage affects negatively to the performance.

Stock price is one of measurement of value of company, it is preferred as it is commonly used as a parameter of firm's value traditionally for public listed companies. It is common that the upper management receive incentives in the form of stock options so they become one of the owners of the company. In order to increase their own wealth, they tend to work hard to lift up the company's stock price. Other than that, it becomes a concern because when stock price falls, the cost of borrowing and issuing new equity cost can rise (Coyne \& Witter, 2002). Macroeconomic condition may affect the stock prices and indicates the 
efficiency of the market. When the price of stock higher, so the value of company's equity is also improved. Lastly for the regression purposes we use ln stock price as measurement of firm value

\section{II.II.I Independent Variables}

CaptStr is the capital structure indicator, proxies by ratio of total debt over total asset. Firm Specific (FS) as control variable variables consist of company size which is measured by total assets of the company, for the regression purpose we use $\ln$ (Assets). This continue variable such as $\ln$ (Assets) is normally expected to be a superior regressor than some arbitrary size dummies variable (Berger et. al, 2010). Another firm specific measurement is revenue growth of the companies(RG). Firm can be categorized as small, medium or large. Essentially, there is no actual standard in determining the size of a firm. Firms that face larger markets are large themselves, principally. Countries with better financial markets, most of average size firms in industries depend on external finance (Bodnaruk, Loughran, \& McDonald, 2013). Revenue growth shows the change of sales over period of time. Commonly, the revenue growth can be achieved with an increase of assets in terms of financial. If the company's growth exceed could not balance its leverage, then the company would likely to suffer financial problem due to its growth rate (Financial Tools, 2010). The formula for revenue growth is as follows:

Revenue Growth $=\frac{\text { Current Revenue-Previous Revenue }}{\text { Previous Revenue }}$

Macro Economics (ME) factors are represented by Gross Domestic Product (GDP) growth and inflation rate (INF). GDP is the best way in measuring the productivity and the economic condition of a country. Data for GDP Indonesia is produced by BPS-Statistic Indonesia which is called as Badan Pusat Statistik (BPS). Indonesian GDP hit 1.290.540 Billion Rupiahs in 2008 and reached 2.367.928 Billion Rupiahs in 2013, with the average growth around 6.1 persen for the last five years. Inflation is the increase of aggregate general price of goods and services. When all prices are creeping upward, thus the standard of living falls. Everything becomes expensive, it will affect performance of company through growth of sales, cost of production as well as financing cost.

\section{RESULTS AND ANALYSIS}

\section{III.I Descriptive Statistics}

The descriptive statistics shows the mean, median, maximum, minimum, standard deviation, skewness, kurtosis, JarqueBera. The mean is the average amount of the observations; median is the middle amount; maximum is the biggest number; and minimum is the least number. Standard deviation shows the variety of data used; it is classified as vary if it is greater than 1 and called as not vary if it is closer to 0 . Skewness, kurtosis, and Jarque-Bera are used to test the normality of the data. Skewness is the degree of asymmetry of a distribution. If a frequency distribution curve has a more lengthened tail to the right (seen from the mean) then it is said to be skewed right (positive) and if otherwise then skewed left (negatively). A normal distribution has a skewness of 0 . Kurtosis is the degree of fineness of a distribution (usually measured relative to the normal distribution). Even more pointed curve of the normal distribution is called leptokurtic, platykurtic flatter and called mesokurtic normal distribution. A 
normal distribution has kurtosis equals to 3 , while leptokurtic distribution usually greater than 3 and platykurtic is less than 3. Jarque-Bera test is classified as a normal distribution with the amount equals to 1 . It is conducted by comparing the probability of Jarque-Bera with 0.1 . If the probability of Jarque-Bera is less than 0.1, the data is classified as a non-normal distribution. Otherwise, if the value of Jarque-Bera is greater than 0.1 , then the data is a normal distribution.

Table 1- Descriptive Statistics

\begin{tabular}{lcccc}
\hline & Capstr R & OA R & OE S & P \\
\hline Mean & 0.529187 & 0.066825 & 0.279399 & 6.684859 \\
Median & 0.511973 & 0.039390 & 0.106969 & 6.491355 \\
Maximum & 2.998186 & 0.460382 & 22.76494 & 10.834670 \\
Minimum & 0.006609 & -0.222551 & -1.420148 & 3.761200 \\
Std. Dev. & 0.342513 & 0.120590 & 2.036558 & 1.759925 \\
Skewness & 3.541261 & 0.373745 & 10.80036 & 0.298484 \\
Kurtosis & 24.43932 & 3.912011 & 119.8394 & 2.293522 \\
Jarque-Bera & 2676.484 & 7.300149 & 74119.65 & 133.7403 \\
Observations & 126 & 126 & 126 & 126 \\
Cross sections 2 & 8 & 282 & 8 & 28 \\
\hline & & & & \\
\hline & & & & \\
\hline Mean & SZ R & G & & \\
Median & 12.90052 & 1.822198 & 5.831508 & 5.361429 \\
Maximum & 13.24481 & 0.012745 & 6.140000 & 5.130000 \\
Minimum & 15.78495 & 215.1413 & 6.500000 & 6.970000 \\
Std. Dev. & 5.656967 & -0.998726 & 4.350000 & 4.280000 \\
Skewness & 2.276881 & 19.16245 & 0.757510 & 0.918944 \\
Kurtosis & -1.575043 & $11.07957-$ & 1.242985 & 0.808289 \\
Jarque-Bera & 5.166711 & 123.8414 & 2.988866 & 2.443949 \\
Probability & 76.74284 & 79241.76 & 32.44592 & 15.34322 \\
Observations & 0.000000 & 0.000000 & 0.000000 & 0.000466 \\
Cross sections 2 & 126 & 126 & 126 & 126 \\
\hline & 8 & 282 & 8 & 28 \\
\hline
\end{tabular}

Source: data processed - EViews 7

Based on table Tablel above, the debt proportion over asset has a mean0.529. This means that the average of total debt of mining companies listed in Indonesia Stock Exchange is $53 \%$ of its asset. Mean for ROA is $7 \%$, maximum return is $46 \%$ while the minimum return is $-22 \%$. Another performance measurement ROE for companies in our sample is 28 percent, much higher than bank time deposit rate in this period (around 6 percent). Average price of stock measured by mean for mining companies listed in Indonesia Stock Exchange is 6.68 (IDR 3,494 ) and median is 6.49 (IDR 590). The most expensive stock $\ln$ is 10.83 (IDR 50,750) while the cheapest stock is 3.76 (IDR 43). Size of firm which is the total assets of the companies, the mean is 12.9 (IDR 10,343,811) and median is 13.2 (IDR1 3,917,589). The maximum asset owned is 15.8 (IDR 82,623,566) while the minimum is 5.7 (IDR 3,062). Mean of Revenue growth is not high for this industry it is only $1.8 \%$ with median $0.013 \%$, however a company has a growth at $215 \%$ while the minimum is $-0.99 \%$. All these data for company specific are not normally distributed as can be seen from its skewness and also Jarque-Bera.

Indonesian macroeconomics data for the period 2009-2013 as follows; GDP growth mean is $5.8 \%$. The highest rate is $6.5 \%$ while the lowest rate is $4.35 \%$. Meanwhile for the same period Indonesian government still keep manage the rate below two digit, where the mean is $5.36 \%$. The highest rate is $6.97 \%$ while the least rate is $4.28 \%$. Both of these macroeconomics data arealso not normally distributed.

\section{III.II Hypothesis Analysis Using Regression Analysis}

This research is going to test the following hypothesis:

Hypothesis 1: Capital structure has a significant effect on financial performance.

Hypothesis 2: Capital structure has a significant effect on firm value.

To test the hypotheses, the regression panel data is applied to determine the appropriate model and followed by t-test to see the relationship between independent variable and the indicators of dependent variables. In addition, the t-test describes which indicator is significant. After that, the F-test is used to see the relationship between the main variables; independent with dependent variables. This test will verify the hypothesis whether it is being accepted or rejected. Last but not least, 
the adjusted R-square test is applied to see how impactful is the significant variables.

There are three main methods available to estimate panel data; they are Pooled Least Square (PLS), Fixed Effects Model (FEM), and Random Effects Model (REM).PLC is also known as Common Effect Model (CEM). This is considered as simple method but inappropriate result. In this model, each observation is treated independently.FEM is statistical method that measures the quantities of explanatory variables which are treated as non-random variables. It also measure time-invariant variables with time-variant effect.REM is also called as Variance Components Estimations. It is used based on an assumption that the effect is assumed to be random(Brooks, 2008). Whether to use PLM, FEM or CEM, we use Chow test and Hausmann Test, and the results of our test show the appropriate method to estimate the parameter of model is random effect (REM).

Table 2.1,shows that only revenue growth which significantly effecting ROA. The value of probability 0.0822 is the only $p$-value under 0.10 (the significant parameter). The revenue growth towards ROA has a negative significant effect as the coefficient is in a negative sign. Although the revenue growth is the control variable, but in this research, it is the only one which associated with the ROA, negatively. This might be possible as the more revenue gained each year; the return on the assets employed is higher if the proportion of additional asset is relatively smaller than the returns.

Table 2.1 - Regression Panel Data Estimation of ROA, ROE and Stock Price (SP)

\begin{tabular}{|c|c|c|c|c|c|c|}
\hline \multirow{2}{*}{ Variable } & \multicolumn{2}{|c|}{ ROA } & \multicolumn{2}{c|}{ ROE } & \multicolumn{2}{c|}{ SP } \\
\cline { 2 - 8 } & Coefficient & Sig. C & oefficient & Sig. C & oefficient \$ & ig. \\
\hline C & -0.0714510 & .8083 & -3.321035 & 0.399 & 8804.65 & 0.3974 \\
\hline Capstr & -0.0680880 & .7993 & 1.42930 & .5972 & -17556.12 & $0.0667^{*}$ \\
\hline SZ 0 & .007419 & 0.3225 & 0.0358710 & .2306 & 836.81350 & $.0042 * *$ \\
\hline RG & -0.0005550 & $.0822^{* * *}$ & -0.002057 & $0.0000^{* * *}$ & 0.5940730 & .8448 \\
\hline GDP 0 & .015148 & 0.1461 & 0.0117840 & .832 & 516.57650 & $.0064^{* * *}$ \\
\hline INF & -0.00437 & 0.4545 & 0.3654010 & .2913 & -243.0717 & 0.114 \\
\hline R Squared & 0.1819430 & \multicolumn{7}{|c|}{.037505} & 0.037505 \\
\hline $\begin{array}{c}\text { Adj. R } \\
\text { Square 0 }\end{array}$ & \multicolumn{3}{|c|}{.140696} & \multicolumn{7}{|c|}{-0.011024} & \multicolumn{3}{c|}{} \\
\hline
\end{tabular}

Source : data - processed

In contrast, the capital structure and other indicators are not associated with the ROA. It is not significantly affecting but the Capstr has an indirect relationship, which means as the debt to asset increases, the ROA decreases. It seems that this mining industries using too much debt to finance their asset $(53 \%)$, they have already passed the optimum of its capital structure, so that when they add more debt, it will affect negatively to its return. To resolve this condition company in this industry have to put more equity capital to increase the return. This result is different from the empirical studies mentioned in previous studies such as Narajini and Priya's (2013) that stated that there is a positive relationship between capital structure and financial performance. This dissimilarity result might be due to the different condition in Indonesia, especially in percentage of debt use to finance their assets by the mining industry in their data.

Similar to the result in ROA, the only indicator significantly associated with ROE is revenue growth, but this one with $\mathrm{p}$-value of 0.0000 . This number might shows a highly significant effect as there is no tolerable error. The effect is negative as well, similar to ROA. Both measurement of capital structure consistently do not 
significantly affect ROE. Thus this might conclude that H1 "capital structure has a significant effect towards financial performance" is rejected. This result different with the finding by Soumadi and Hayajneh (2012), they found there is a negative relationship because of the debt acquired by the companies. When a company use more debt financing, it might emerge the bankruptcy risks that decrease the tax shields, thus minimize the financial performance.

Size of company consistently has positive associated with the performance and value of company, even though it is only significant positive relationship with stock price. It seem that the bigger the company the more return the company can have, probably because of their market share and also product diversification, as many of mining companies in Indonesia owned by business conglomerate that have good reputation and strong equity capital.

From the Random Effect Model of stock price above, there are three other indicators that significantly associated with the stock price, which represents the firm value. Both measurement of capital structure have a negative relationship. When the debt increases, the business risk increases therefore the stock price fall as the risk discourage the investor to invest. Moreover, when the equity increases number of dividend could increase thus the proportion received is smaller, and this causes the investor doubtful to invest in the company, causing decline in the stock price is falling.

GDP and the size of company rate are more impactful towards the firm value compare to capital structure. Both of them are positively significant towards stock price. This means the bigger the size of the assets and the higher the GDP, the stock price increases. In contrast, the revenue growth and inflation rate has no association with the stock price. From this model, the H2 "capital structure has a significant effect towards firm value" is therefore accepted.

This result is in contrast with the MM irrelevance proposition which stating that the firm's value is irrelevant to its capital structure. However, it proves the Modigliani and Miller second research after the irrelevance proposition that the capital structure has a significant effect towards firm value in the condition of imperfect market (Modigliani \& Miller, 1963). Moreover, the Capstr which represents the total debts over assets is slightly proves the pecking order theory by Myers and Majluf (1984) and Myers (1984) trade-off theory. In addition, the empirical researches of Chowdhurry (2010) which resulted in negatively significant relationship between capital structure and firm's value. Ogbulu and Emeni

\section{CONCLUSION}

This research analyzes the impact of capital structure towards the financial performance and firm value of the Mining companies listed in Indonesia Stock Exchange from the year 2009 to 2013. The samples are 28 mining companies listed in Indonesia Stock Exchange. The main variable are capital structure, measured by total debts over total assets (TD/TA) as an independent variable; profitability as financial performance measured by returns on assets (ROA) and returns on equities (ROE), and firm value, measured by stock price, as the dependent variables; and there are two controlled variable which are external factor such as GDP rate and inflation rate, and internal factor such as revenue growth and firm 
size (total asset).

From the data analysis we find that leverage has negative impact on the firm performance (ROA) as well as on firm value (SP), it seem that the mining industry in Indonesia has already passed its optimal capital structure, so that the more debt financing they have the worse their performance. However this result is not significant, thus we are rejecting the first hypothesis, "Capital structure has a significant effect towards financial performance". The capital structure which is measured by the debt proportion over assets has no effect on financial profitability. The indicators that significantly affect financial profitability come from the control variable, which is revenue growth. It shows a highly significant effect towards financial statement (ROA and ROE). For the second hypothesis, "Capital structure has a significant effect towards firm value" is accepted. The capital structure shows a significant effect as it is less than $10 \%$ limitation. However, the firm size and GDP rate is more impactful towards firm value.

This research has some limitations such as the small number of samples, the shortness of time range observations, and the number of indicators used. In order to improve the result we suggest some recommendations for future research for example using market indicators of performance such as earning per share, meanwhile for firm value probably economic value added cold be implemented

\section{BIBLIOGRAPHY}

Ak, B. K., Dechow, P. M., Sun, Y., \& Wang, A. Y. (2013). The Use of Financial Ratio Models to Help Investors Predict and
Interpret Significant Corporate Events. Australian Journal of Management

Berger, A.N., Hasan, I., Zhou, M. (2010). The Effect of Focus Versus Differsification on Bank Performance. Journal of Banking and Finance, vol 34, 1417-1435

Bhandari, L.C. (1988). Debt/Equity Ratio and Expected Common Stock Returns:Empirical Evidence. Journal of Finance 43:2, 507-528

Bradley, M., Jarrell, G. A., \& Kim, E. H. (1984). On the Existence of an Optimual Capital Structure: Theory and Evidence. The Journal of Finance Vol. 39 No. 3 , 857-878.

Bodnaruk, A., Loughran, T., \& McDonald, B. (2013 йил 28-September). Using 10-K Text to Gauge Financial Constraints.

Brooks, C. (2008). Introductory Econometrics for Finance. New York: Cambridge University Press.

Chandra,P.(2011). Financial Management. New Delhi: Tata McGraw Hill

Coyne, K. P., \& Witter, J. W. (2002). What Makes Your Stock Price Go Up and Down. The McKinsey Quarterly, 2002, No. 2

Chowdhurry. (2010). Impact of Capital Structure on Firm's Value: Evidence from Bangladesh. Business and Economic Horizons , 111-122.

D'Amato, E. (2010). The Top 15 Financial Ratios. New South Wales: Lincoln.

Dimitrov, Valentin and Jain. P.C. (2008). The Value Relevance of Changes in Financial Leverage beyond Growth in Asset and GAAP Earning. Journal of Accounting, Auditing and Finance, vol 23-2, 191-222

Fama, Eugene.F. (1980). Agency Problems and Theory of the Firm. The Journal of 
Political Economy, 88 (2) p.288-307.

Financial Tools. (2010, February 26). How is Actual Sales Growth Rate Calculated?

Grossman, S.J., Hart,O. (1982). Corporate financial structure and managerial incentives. In: McCall, J. (Ed). The Economics of Information and Uncertatinty. University of Chicago Press, Chicago.

Jaisawal, B., Srivastava, N., \& Sushma. (2013). Role of Capital Structure in Defining Financial Performance: A Study with Respect to Cement Industry in India. International Journal of Applied Financial Management Perspectives Vol. 2 No.3, 537-547.

Jensen, M.C. and W. Meckling (1976). 'Theory of the Firm; Managerial Behaviour, Agency Cost, and Ownership Structure', Journal of Financial Economics, 3, p. 305-360

Jensen, M.C (1986),' Agency Cost of Free Cash Flow, Corporate Finance and Take Overs'. American Economic Review Papers and Proceeding, 76, p. 323-329

Khan, K. I. (2012). Effect of Dividends on Stock Prices: A Case of Chemical and Pharmaceutical Industry of Pakistan. 2nd International Conference on Business Management (pp. 1-23). Lahore: University of Management and Technology, Lahore.

Luigi, P., \& Sorin, V. (2009). A Review of The Capital Structures Theories. Finances, Banks, and Accountancy Vol.3 , 315-320.

Masulis, R.W. (1983). The Impact of Capital Structure Change on Firm Value: Some Estimate. Journal of Finance 38:1, 107-126

Margaritis, D., \& Psillaki, M. (2009). Capital Structure, Equity Ownership and Firm Performance. Journal of Banking and Finance $34,621-632$.

Modigliani, F., \& Miller, M. H. (1963). Corporate Income Taxes and the Cost of Capital: A Correction. The American Economic Review, Vol. 52, No. 3 , 433443.

Myers, S. C. (2001). Capital Structure. The Journal of Economic Perspectives Vol, 15 No.2, 81-102.

Myers, S. C. (1984). The Capital Structure Puzzle. The Journal of Finance Vol. 39 No. 3 , 575-592.

Modigliani, F., \& Miller, M. H. (1958). The Cost of Capital, Corporation Finance, and the Theory of Investment. The American Economic Review Vol. XLVIII No. 3 , 262-297

Morck, R., Shleifer, A. dan Vishny, R.W., (1988). Management Ownership and market Valuation: an Empirical Analysis. Journal of Financial Economics 20, p.293-315.

Nirajini, A., \& Priya, K. B. (2013). Impact of Capital Structure on Financial Performance of the Listed Trading Companies in Sri Lanka. International Journal of Scientific and Research Publications. Vol. 3 , 1-9.

Ogbulu, O. M., \& Emeni, F. K. (2012). Capital Structure and Firm Value: Empirical Evidence from Nigeria. International Journal of Business and Social Science, 252-261.

Pastory, D., Marobhe, M., \& Kaaya, I. (2013). The Relationship between Capital Structure and Commercial Bank Performance: A Panel Data Analysis. International Journal of Finance Economics Vol. 1 No. 1, 33-41

Pratheepkanth, P. (2011). Capital Structure and Financial Performance: Evidence from Selected Business Companies in 
Colombo Stock Exchange Sri Lanka. 'Environmental Dynamism, Capital Researchers World - Journal of Arts, Structure an Performance: a Teoritical Science \& Commerce, 171-183.

Pouraghajan, A., Malekian, E., Emamgholipour, M., Lotfollahpour, V., \& Bagheri, M. M. (2012). The Relationship between Capital Structure and Firm Performance - Evaluation Measure: Evidence from the Tehran Stock Exchange . International Journal of Business and Commerce Vol. 1, No. 9 , 166-181

Ross, S. Jordan. (2009). Fundamental of Corporate Finance. Mc Graww Hill

Simerly, R. L \& Li, Minfang, (2000), Integration and an Empirical Test', Strategic Management Journal , 21; p.3149

Soumadi, M. M., \& Hayajneh, O. S. (2012). Capital Structure and Corporate Performance: Empirical Study on the Public Jordanian Shareholdings Firms Listed in the Amman Stock Market. European Scientific Journal - Vol.8, No. $22,173-189$.

Statistics Indonesia of The Republic Indonesia. (2009). Gross Domestic Product. 